Original Research
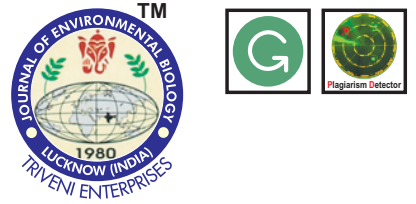

DOI : http://doi.org/10.22438/jeb/38/5/MRN-381

\title{
Alpine marmot populations after four decades of living in the glacial areas of the Făgăraş, Rodna and Retezat Mountains, Romania
}

\section{Authors Info}

S. Geacu and M. Dumitraşcu* Department of Physical Geography, Institute of Geography, Romanian Academy, 12 Dimitrie Racoviţă Street, 023993, Sector 2, Bucharest, Romania

*Corresponding Author Email : stefania_dumitrascu@yahoo.com

Key words

Alpine marmot, Făgăraş mountain, Retezat mountain, Rodna mountain

\section{Publication Info}

Paper received : 10.06 .2016

Revised received : 29.09.2016

Re-revised received : 13.02 .2017

Accepted : 28.03.2017

\section{Abstract}

Aim : To highlight the situation of the alpine marmot (Marmota marmota) after four decades of colonisation in three mountain ranges of Romania: the Făgăraş, Rodna and Retezat.

Methodology : To reach this target, summer field investigations have been conducted in various areas of the three mountain ranges, and in the archives of central and local forest and hunting administrative units, with a view to identify the data needed to establish the dynamics of these populations.

Results : A synthesis study has been made to point out the population dynamics of this rodent (Sciuridae Family), the connection between populations and the geographical conditions in the glacial areas of the three mountain groups of the Eastern and Southern Carpathians.

Interpretation : A typical rodent of the Alpine regions, the alpine marmot s are perfectly integrated in thair new habitats with several colonies of these populations in each mountain group. At the same time, the species has extended its areas by up to $20 \mathrm{~km}$.
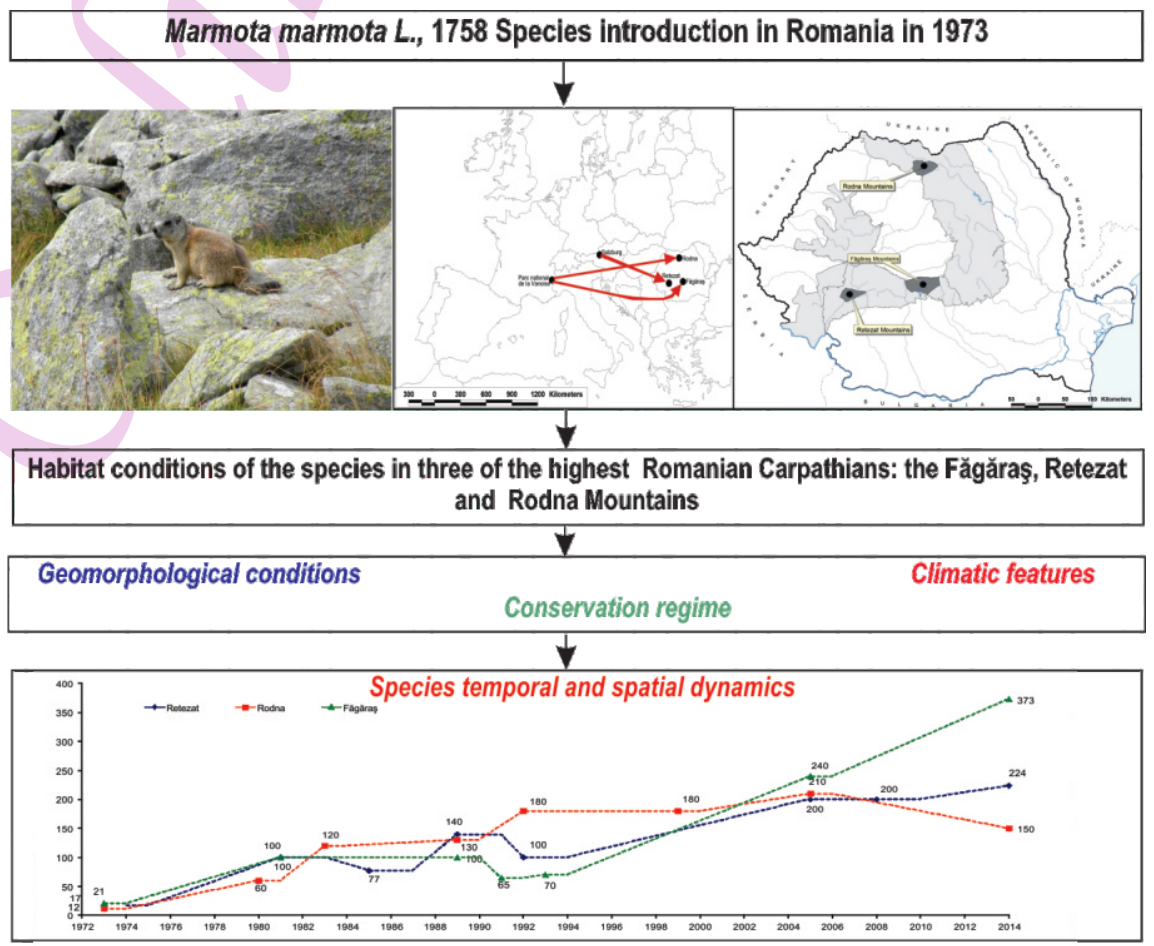


\section{Introduction}

A rodent mammal, Marmota marmota lives in the alpine habitats of the highest mountains in Europe (Pyrenees, Alps and Carpathians). The mammal belongs to Order : Rodentia Bodwich, 1821; Family : Sciuridae Gray, 1821 and Genus : Marmota Blumenbach, 1779 (Wilson and Reeder, 1993).

Studies performed in the Tatra Mountains (Bačkor 2009), Rodna Mountains (Szabo, 2010), the French and Italian Alps (Allainé et al., 1994; Borgo, 2003) and the Pyrenees (Herrero et al., 1994) revealed significant information on species current distribution, dynamics and habitat requirements in the mountaineous areas of Europe.

In Romania, Marmota marmota was introduced to the tallest Romanian Carpathians, which is, Făgăraş and Retezat (Southern Carpathians) and Rodna (Eastern Carpathians) (Almăşan, 1981; Geacu, 2006).

As herbaceous species, the alpine marmot feeds on the short plants (Carex curvula, Juncus trifidus, Agrostis rupestris, Festuca airoides, Nardus stricta, Sesleria tenuifolia and Poa alpina) that grow in alpine meadows and are well-adapted to cold and strong winds. It also eats the lickhens that gnaw on rocks, e.g. Cetraria islandica or Cladonia rangiferina, and grows at the bark of dwarf bushes such as Loiseleuria procumbens of the alpine zone. The alpine marmot also eat the fruits of some species like Vaccinium myrtillus and Vaccinium vitis-idaea. Alpine marmots are fond of sunny slopes and if nothing disturbs them, they may bathe in the sun for hours on end. Between October to April, the animal hibernates, the entrance to the galleries being closed with stones, grass and earth (Năidăşan, 2000). Moreover, some studies refer to the impact of global climate changes on the shortening of the hibernation period (Inouye et al., 2000, Dolenec and Dolenec, 2011).

It has been considered that the alpine marmot inhabited the highest areas of Rodna, Făgăraş and Retezat Mountains during the $19^{\text {th }}$ century (Bielz, 1888; Csato, 1867), whereto it has been disappeared between 1890 and 1900 (Călinescu, 1931; Filipaşcu, 1969). Species' existence in Romania was contested by Rosetti-Bălănescu, (1973) by arguing the absence of any reference to this species in the Romanian folklore or the toponimy of this space (Benedek, 2014). However, a proposal for having the species reintroduced in Romania dates back to 1949 , but it was only in 1965, when Almăşan stressed upon the « need to begin acting to this end as soon as possible » (p. 12), that their future habitat (Făgăraş and Retezat Mountains) was being designated (Almăşan, 1965). The first 50 alpine marmot individuals were brought into Romania in 1973, having been captured in the Alps. Out of the 33 animals caught in the Vanoise National Park (France), 21 were released in the Făgăraş Mountains and 12 in the Rodna Mountains. A number of 17 individuals came from Salzburg region (Austria) and were released in the Retezat Mountains (Fig. 1A, Fig. 1B).
The current paper focuses on the analysis of the spatial and temporal dynamics of Marmota marmota in the three aforementioned areas in close connection with their habitat requirements and the conservation regime. The study was carried out for the past four decades, a period which followed species' introduction or re-introduction in the fauna of the Romanian Carpathians using the data provided by the Romanian Forest Divisions which overlapped Rodna, Făgăraşand Retezat Mountains.

Study area : The present study was carried out in three of the highest Romanian Carpathians Mountains: the Făgăraş and Retezat in the Southern Carpathians and the Rodna Mountains in the Eastern Carpathians (Fig. 1B), all being built predominantly of crystalline schists (Niculescu and Badea, 2006). They have the most impressive glacial relief (glacial cirques and valleys) of all mountain ranges in this country (Niculescu et al., 1973). Springs on slopes and glacial lakes represent water sources for the alpine marmot.

\section{Materials and Methods}

At the time the first alpine marmots were brought into Romania, the researches were focused primarily on identifying the first documents issued by various forestry and cynegetic institutions. Later on, studies performed in the selected casestudies aimed at establishing the population dynamics and species habitat characteristics. The assessment of long-term dynamics relied on the data recorded by the rangers of the Forest Divisions in the analysed mountain areas. Thereby, in 2011 and 2012 the authors carried out direct field observations in the areas where alpine marmots used to live during summertime. Based on the visual observations (using binoculars) conducted during the field surveys, the authors were able to map several alpine marmot habitats and movement routes.

\section{Results and Discussion}

The Făgăraş Mountains : The Făgăraş Mountains covers approximately $1,500 \mathrm{~km}^{2}$ with a dominant altitude of 2,400$2,500 \mathrm{~m}$ a.s.l., favouring the development of alpine and subalpine levels. Likewise, the massif features a significant glacial relief inherited also from periglacial processes of extensive spatial dynamic (Voiculescu, 2002; Voiculescu and Ardelean, 2012). It also preserves the widest glacial area in Romania, especially on the main summit which is about $70 \mathrm{~km}$ long from west to east, with maximum elevation in the country: the Moldoveanu (2,544 $\mathrm{m}$ a.s. I.) and the Negoiu (2,535 $\mathrm{m}$ a.s.l.) peaks. Here, one may see complex glacial cirques, up to $8 \mathrm{~km}$ long glacial valleys and 25 glacial lakes (e.g. Lacul Doamnei Lake of the Lady 0.5 ha and Podrăgel Lake -0.7 ha lie at 1,860 $\mathrm{m}$ a.s.l. and 2,030 m a.s.l., respectively) (Niculescu, 1973; Velcea and Popova, 1987) (Fig. 2).

At Bâlea Lac weather station (2,038 $\mathrm{m}$ a.s.I.), the mean annual air temperature is only $0.2^{\circ} \mathrm{C}$, with a maximum of $8.8^{\circ} \mathrm{C}$ ) in 
August and a minimum of $-8.4^{\circ} \mathrm{C}$ in February (Fig. 3A) ; the mean annual rainfall reaches $1215 \mathrm{~mm}$ (Sandu et al., 2008). The dominant winds blow from the north (21.1\%) (Voiculescu, 2002). The annual number of days with snow cover is 150 , except for the summer and the first half of winter when no such days are registered (Fig. 3B).

The habitat conditions of the upper Făgăraş Mountains are favourable to the alpine marmot. The species was introduced in the area in July 1973, when 21 alpine marmots were brought from the French Alps and were released in the glacial cirque at the sources of the Arpăşel Valley (northern slope of Făgăraş Mountains, Sibiu County). Here, the staff of the Arpas Forest Range built man-made galleries in order to host them and prohibited the grazing of farm animals. This action enjoyed the support of the Inspection for the Economy of Hunting of the Ministry of Forest Economy and Building Materials (Almășan, 1981). At the beginning, the alpine marmots settled at 1,9002,000 $\mathrm{m}$ a.s.l., subsequently extending their area at higher elevations. The animals soon left the man-made galleries, digging themselves others in the source area of the Arpăşel Valley. In 1981, their number had increased to some 100 individuals in the Arpasşel glacial cirque. The locals would name the place "Alpine Marmot Hollow" (Almăşan, 1981).

By the end of 1980, the animals expanded their area eastwards in the eastern sector of Făgăraş Mountains (Braşov County); in 1989, about 40 specimens were found to live there. Overall, in the Făgăraş Mountains, 100 individuals were signalled in 1989 of which 65 remained in 1991 and around 70 in 1993. Consequently, the alpine marmots shifted to the southern slopes, extending their habitat towards west (up to $9 \mathrm{~km}$ as far as the glacial cirques of Negoiu and Şerbota peaks) and east (e.g. towards the Podrăgel glacial cirque). In 2005, the Făgăraş Mountains held 240 specimens of which 190 on the northern slopes (115 in Sibiu County and 75 in Braşov County) and 50 on the southern slopes (Argeş County). As a matter of fact, the first alpine marmots were introduced in Sibiu County, but very near to its boundaries with Braşov and Argeş counties. Apart from Arpăşel glacial cirque, specimens could be seen also in the glacial cirques Albota, Arpăşelul Mare, Şerbota, Doamnei, Podrăgelul, Laiţa and Târla Mare. In 2014, this mountain sector held 373 individuals (57.6\% in Sibiu County, $27.9 \%$ in Brasov County and $14.5 \%$ in Argeș County), $85.5 \%$ of the observed individuals are found on the northern slope.

The Retezat Mountains : The Retezat Mountains are situated on the west side of the Southern Carpathians. The highest peaks are Peleaga (2,509 $\mathrm{m}$ a.s.I.), Retezat $(2,482 \mathrm{~m}$ a.s.I.) and Bucura (2,433 m a.s.l.). The whole area extends over $453 \mathrm{~km}^{2}$, but the alpine relief (above 1,800 m) represents $27 \%$ of the surface (Urdea, 2001). In the central part of the Retezat Mountains, the main landscape features are shaped by the glacial relief which consists of rocky peaks and crests, huge glacial cirques with vast screes, and glacial valleys (Niculescu, 1973; Urdea, 2000) (Fig. 4).
Outstanding among the 58 glacial lakes are Bucura (10 ha), Zănoaga (29 m, the deepest glacial lake in Romania) and Gemenele (2.5 ha) (Pişota, 1971; Gâştescu, 1971; Popovici, 1993). At Tarcu weather station (2,180 $\mathrm{m}$ a.s.I), situated in the neighbouring mountain sector, the mean annual air temperature is negative $\left(-0.6^{\circ} \mathrm{C}\right)$, with a maximum value in August $\left(7.7^{\circ} \mathrm{C}\right)$ and a minimum in February $\left(-8.6^{\circ} \mathrm{C}\right)$ (Fig. $\left.5 \mathrm{~A}\right)$. The mean annual precipitation sums up to $939.4 \mathrm{~mm}$. The dominant wind blows from the north $(21.5 \%)$ and the snow cover may appear in the first decade of September and it lasts until July or August (Fig. 5B). The annual number of days with snow cover was 190 days on average (Dragne et al., 2004).

The upper part of the Retezat Mountains was established in 1935 as the first national park in Romania (10,000 ha). Currently, the surface of this protected area has been extended to 38,047 ha, of which 1,630 ha is covered by Gemenele Scientific Reserve. In 1973, 17 alpine marmots, brought from the Austrian Alps, were released in Gemenele Scientific Reserve, the endeavour being supported by the Commission for the Monuments of Nature of the Romanian Academy, and by the Strasbourg-based European Council of Information for Nature Protection. Shortly after, all the individuals introduced at the site named « Faţa Retezatului » (The Retezat Frontface) moved to the Bucura glacial cirque (the homonymous lake lying at 2,041 m a.s.l.), because of a Vipera berus reptile, whose bite is fatal for the alpine marmot (Almăşan et al., 1986). Later, on, the species would expand its territory in the neighbourhood, namely the Gemenele glacial cirque, and also in the vicinity of the lakes Ştirbu, Tăul Agăţat and Tăul Negru.

Field surveys and scientific literature (Almăşan, 1986; Benedek, 2006) revealed that glacial cirques are the favourite habitats for the alpine marmots. The main glacial lakes in the Retezat Mountains in the surrounding of which alpine marmots were observed is described in the Table 1 (Gâştescu, 1971).

Numerous specimens occurred in the glacial cirque that hosts lakes Bucura, Ana and Lia. In 1978, alpine marmots were seen at 2,200 m a.s.I below the Slăveiu Mare Peak $(2,346 \mathrm{~m}$ a.s.l.); in 1980, they were found roamed in Judele Mount, too (2,398 m a.s.I.), but also near the Tăul Ascuns Lake. In 1981, the

Table 1 : Main characteristics of some glacial lakes in the Retezat Mountains (Gâştescu, 1971)

\begin{tabular}{llll}
\hline No. & Lake & Surface (ha) & Altitude (m a.s.l) \\
\hline 1. & Bucura & 8.9 & 2,041 \\
2. & Gemenele & 2.5 & 1,900 \\
3. & Tăul Negru & 4.0 & 2,025 \\
4. & Ana & 3.1 & 1,979 \\
5. & Lia & 1.3 & 1,930 \\
6. & Ştirbu & 0.9 & 2,090 \\
7. & Tăul Ascuns & 0.4 & 2,180 \\
8. & Tăul Agăţat & 0.1 & 2,208 \\
\hline
\end{tabular}




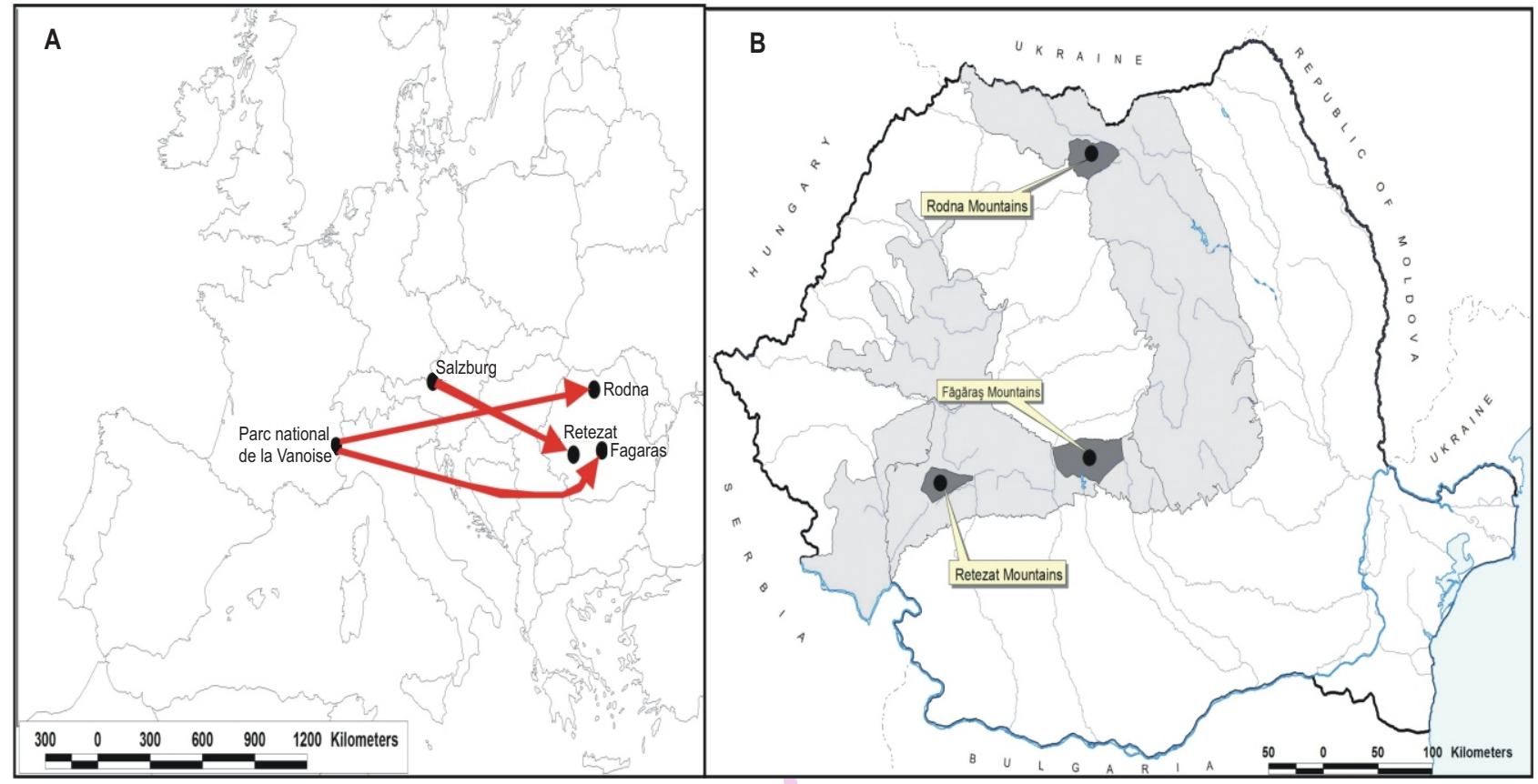

Fig. 1 : (A) Alpine marmots regions of origin and colonisation sites in 1973; (B) Position of case- study area in Romanian Carpathian Range

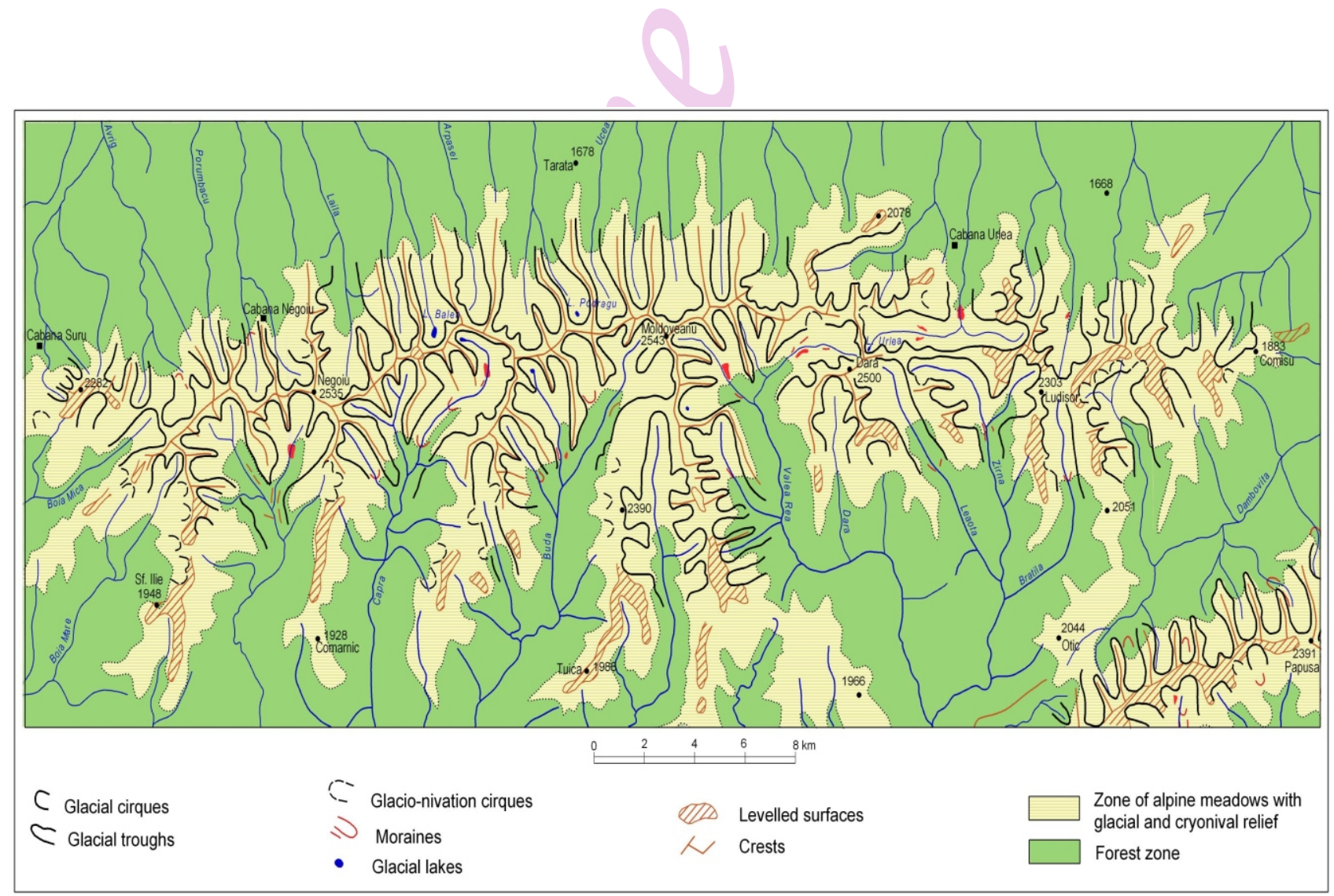

Fig. 2 : Glacial relief in Făgăraş Mountains (source: Niculescu, 1973, map modified by the authors) 

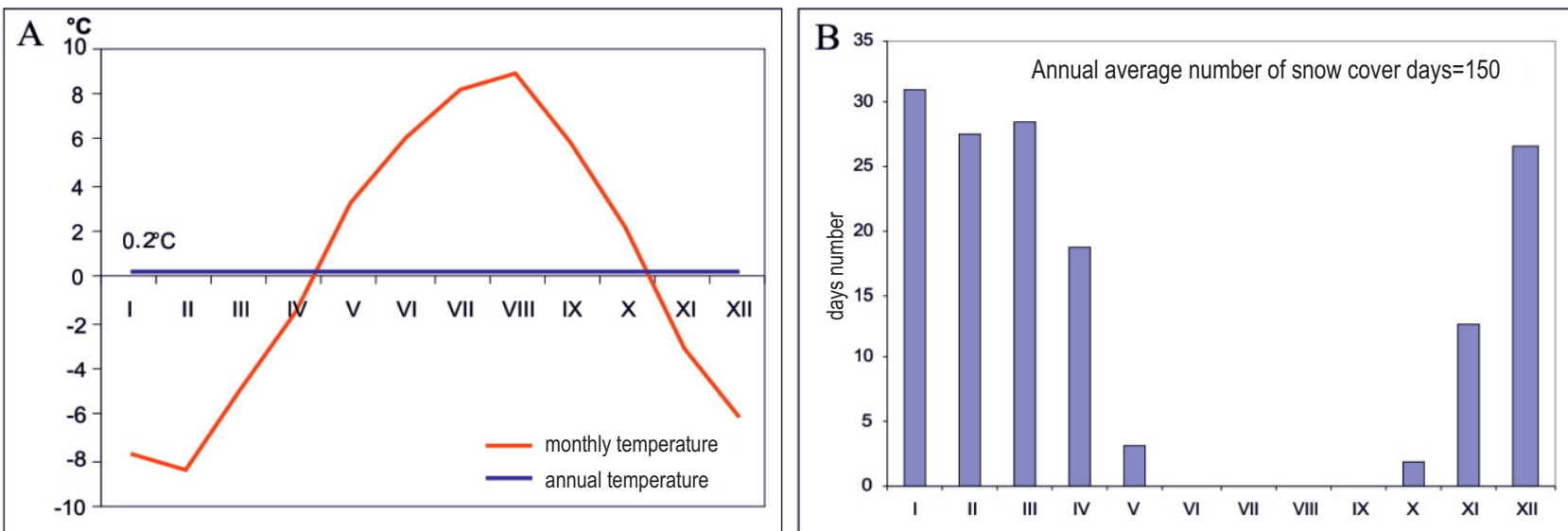

Fig. 3 : (A) Monthly variation of air temperature and (B) number of snow cover days at Bâlea Lac weather station (1961-2000)

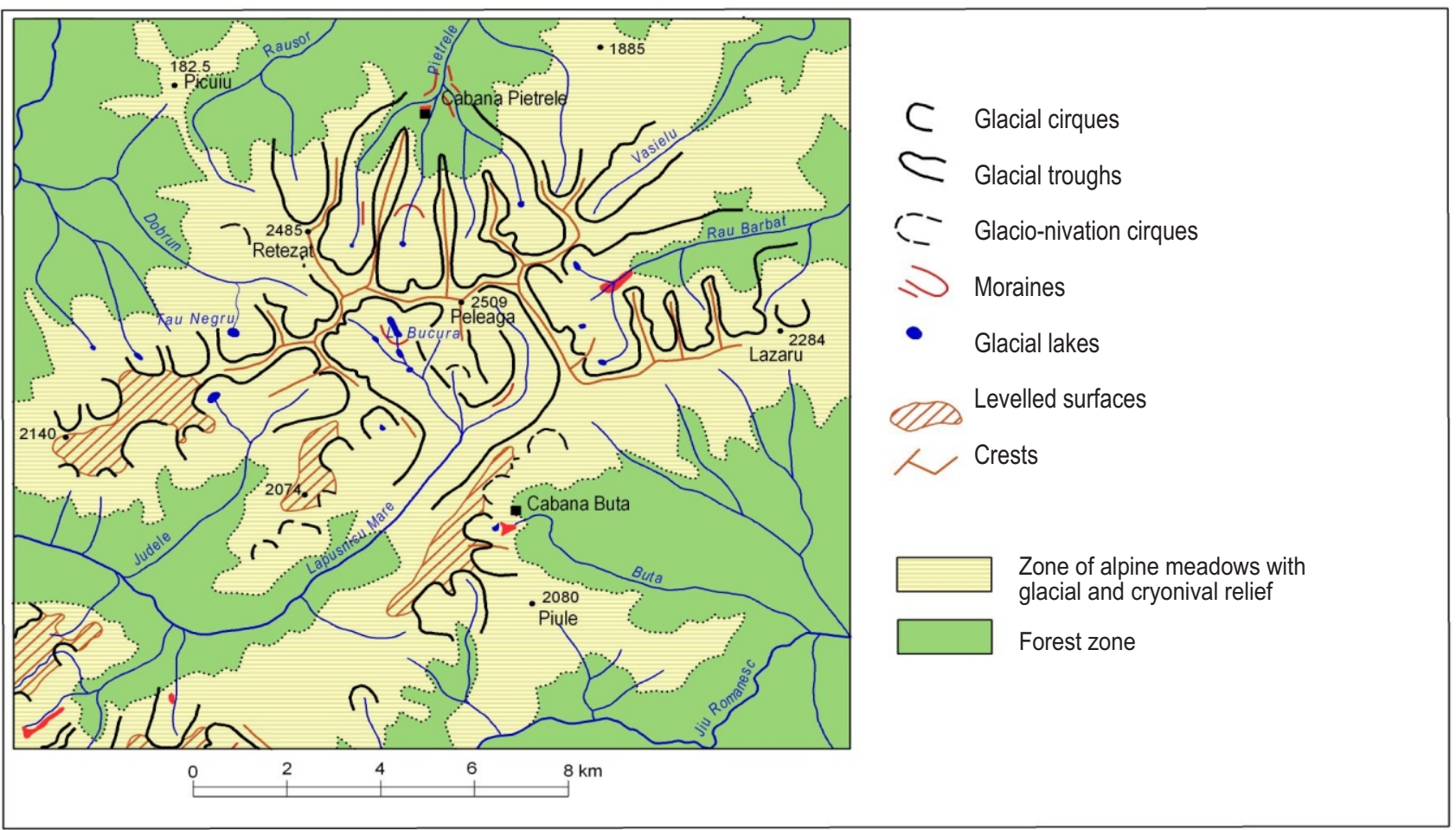

Fig. 4 : Glacial relief in the Retezat Mountains (source: Niculescu, 1973, map modified by the authors)

Retezat Mountains held about 100 individuals, 77 in 1985, 140 in 1989 and 100 in 1992. In 2005, a number of 200 alpine marmots were recorded, while in 2014 increased upto 224.

The Rodna Mountains are the highest mountains in the area located in the northern part of the Eastern Romanian Carpathians, Because of their high altitude, the Rodna Mountains are affected by the Quaternary glaciations featuring one of the most imposing alpine landscapes in the Romanian Carpathians with best preserved glacial and periglacial landforms (Dragotă and Kucsicsa, 2011; Kucsicsa, 2013). The glacial topography includes glacial cirques (the Pietrosu, Buhăiescu, Repede, Negoiescu, Cimpoiesei, Bistriţei Aurii, Ineu and Lala), moraines (in the Lala, Bila, Putredu and Bistricioara valleys), erratic blocks and glacial valleys (Fig. 6).

The number of glacial lakes, which lie behind some moraine deposits, is around 30 . They are located between 1,750 m a.s.I and 1,950 m a.s.I (Gâştescu 1971; Kucsicsa 2013), over a surface-area under 0.5 ha and maximum depth of $5.2 \mathrm{~m}$ (Buhăiescu II Lake) (Chiş, 2010). In the alpine area, the mean 

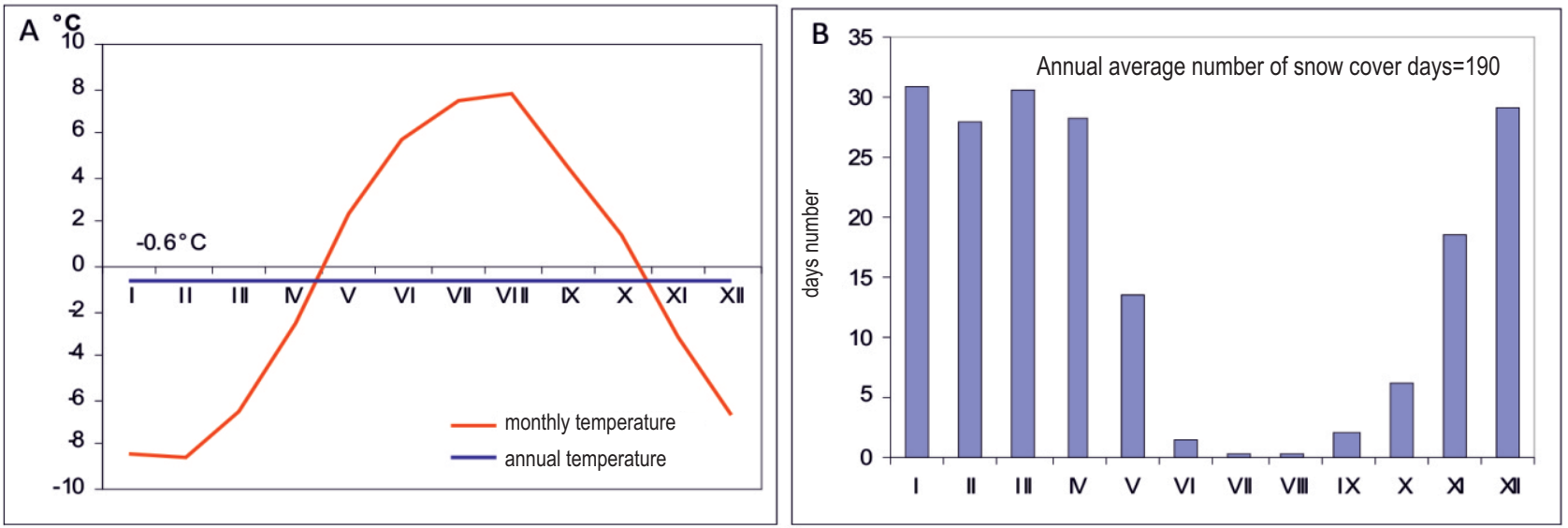

Fig. 5 : (A) Monthly variation of air temperature and (B) number of snow cover days at Tarcu weather station (1961-2000)

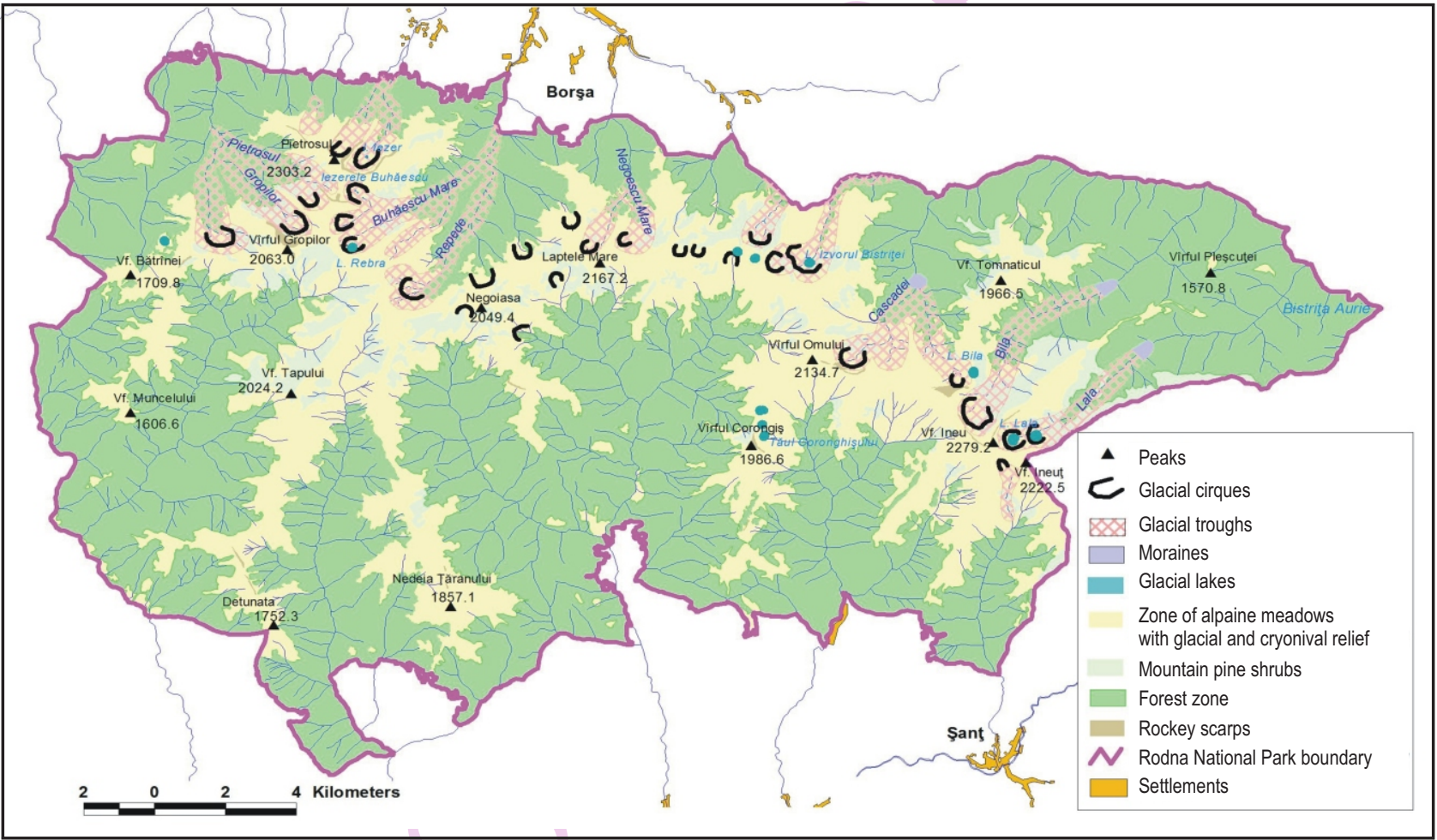

Fig. 6 : Glacial relief in the Rodna Mountains (source: Kucsicsa, 2013, map modified by the authors)

annual air temperature is negative $\left(-1.3^{\circ} \mathrm{C}\right.$ at over $2,300 \mathrm{~m}$ a.s.I. $)$, but at lezer weather station $(1,770 \mathrm{~m}$ a.s.l.) the annual average temperature is $1.5^{\circ} \mathrm{C}$ (Kucsicsa, 2013; Chiş, 2010). The monthly mean temperature is negative between November and March (Fig. 7A). The mean annual precipitation is $1263 \mathrm{~mm}$.

Snow cover may appear in the first decade of September and last until July or August (Fig. 7B). The annual number of days with snow cover was 175 days on average (Dragne et al., 2004; Kucsicsa, 2013). The dominant winds (15\%) blow from the southwest speeding up with 3.5-4.5 $\mathrm{msec}^{-1}$ on average (Kucsicsa, 2013).
The Rodna Mountains stands as the only west-east ridge $(20 \mathrm{~km}$ long) that still preserves traces of Quaternary glaciation, which has high population of alpine marmots. The animals were released close to the tallest peak: Pietrosu $(2,303$ $m$ a.s.I.). Where glacial cirques and valleys, as well as 30 glacial lakes are present. In 1973, shortly after the species had been introduced in the Făgăraş Mountains, 12 individuals from the same batch originating in the French Alps were released on the south/south-west slope of Mount Pietrosu (Almășan, 1981) inside Pietrosu Mare Reserve created in 1962 and given a Biosphere Reserve status in 1979 (Bălteanu et al., 2006). This 

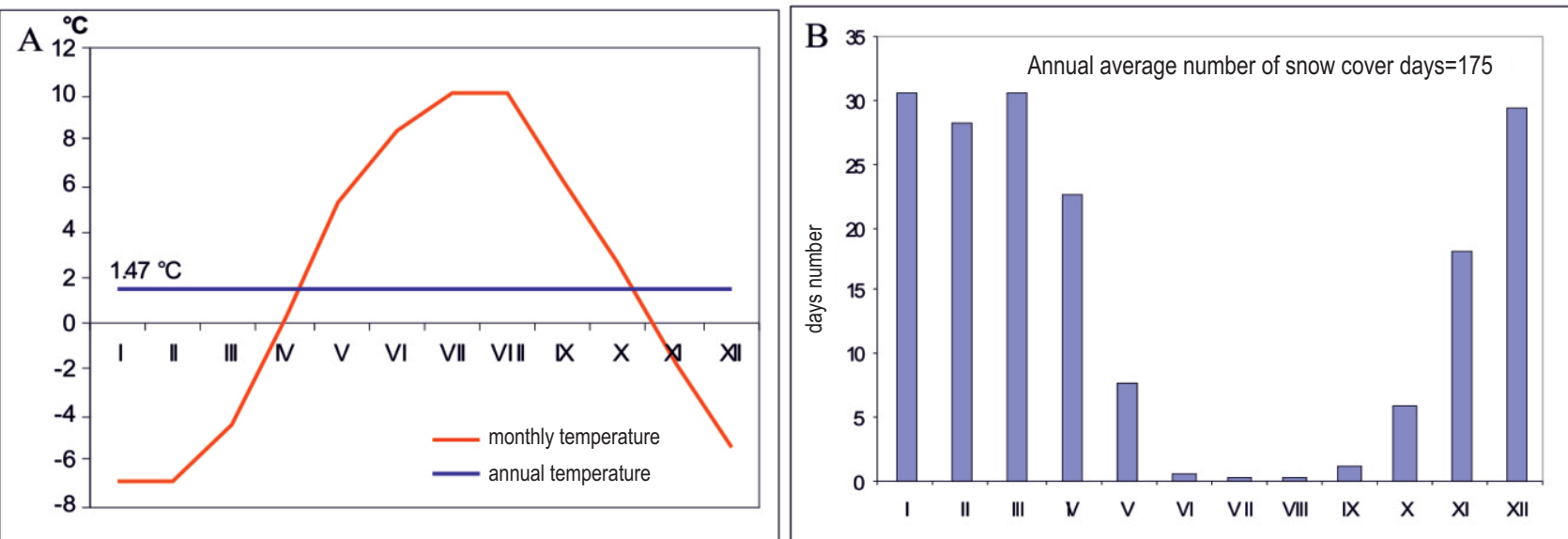

Fig. 7 : (A) Monthly variation of air temperature and (B) number of snow cover days at lezer weather station (1961-2000)

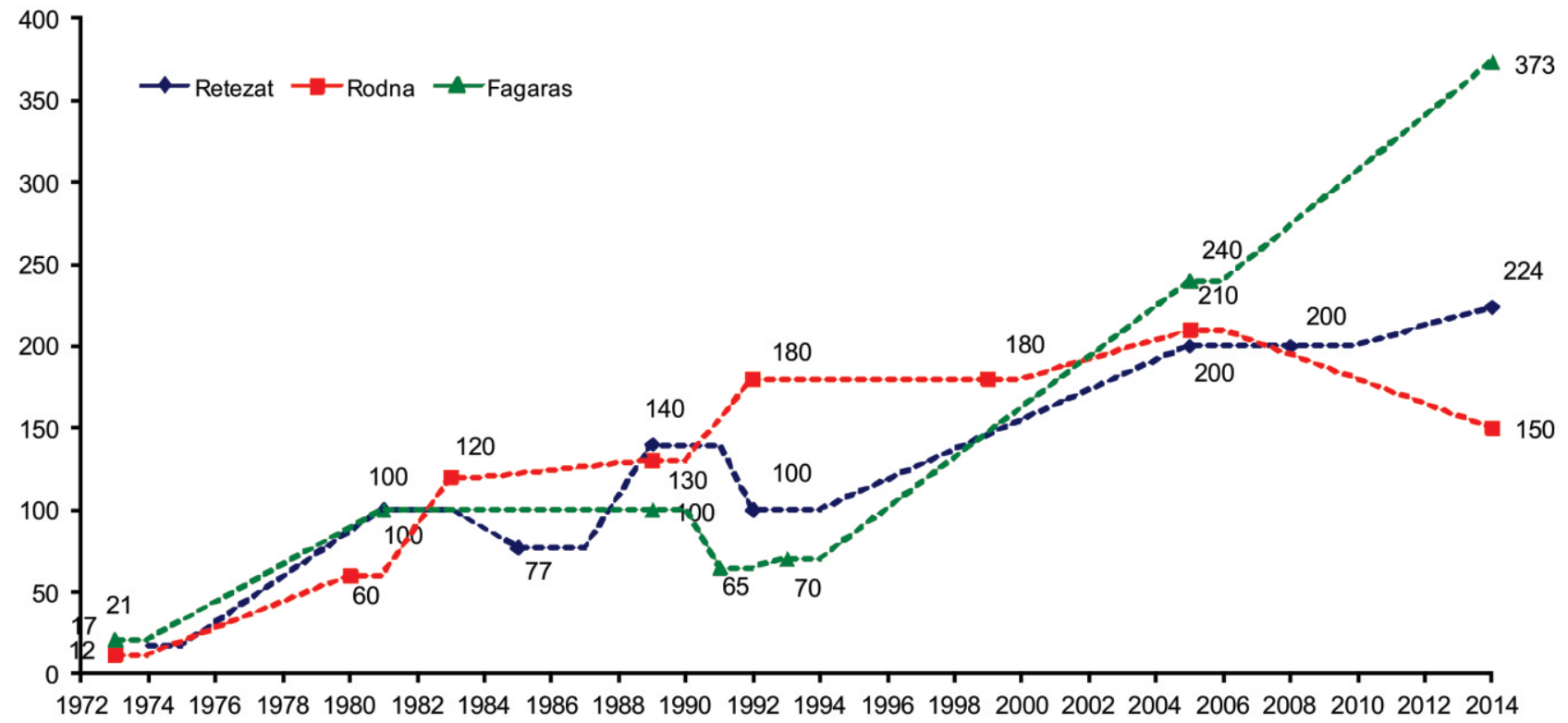

Fig. 8 : Alpine marmot population dynamics in the three Romanian Carpathian ranges (1973-2014)

development benefitted from the support of the former Bucharest-based Inspection for Game Economy.

In the beginning, Reserve guards would build the animal galleries. But, introducing, species introduction was considered to be a failed attempt given that the galleries had been deserted. However, two years later, in 1975, a first alpine marmot colony was detected at some distance (from the early place of release), namely in Zănoaga Mare glacial cirque on the northern side of Mount Pietrosu (Pânzariu, 1993). It appeared that the alpine marmots had settled from 1,700, m a.s.l. (the initial introduction site) to 1,800-2,000 m, some individuals were observed at 2,200 m a.s.l.
In June 1977, the species extended its territory eastwards, to Bistriţa-Năsăud County, alpine marmots being seen in the direction of Gărgălău Mount (2,159 m a.s.I.). In 1980, the Rodna Mountains alpine marmots numbered 60 individuals (grouped into 8 colonies), the population nearly doubling till 1983. In 1989, they counted 130 individuals (120 specimens in the Maramureş County sector and only 10 in Bistriţa-Năsăud). The year 1992 registered 180 alpine marmots, 165 in Maramureş and 15 in Bistriţa-Năsăud County.

In 1993, some individuals were signalled out east of the Puzdrele Peak (2,191 m a.s.I.), in the Negoiescu Valley. In 1999, the Rodna Mountains alpine level numbered 180 specimens and 
around 210 in 2005. Most entrances are oriented to the East, South, South-East and South-West (Szabo, 2010). In 2011, 150 specimens were observed, all of them on northern slopes in Maramureș County.

The species was seen in the glacial cirques Zănoaga Mare, lezer and Buhăescu, in the Pietrosu Mare and Piatra Neagră mountains, reaching as far as Gărgălău Mount to the east. The guards of the Rodna Mountains National Park name Zănoaga Mare glacial cirque "The Marmot Pit ». The expansion of the species' area towards the Corongiş $(1,987 \mathrm{~m}$ a.s.I.) and Ineu (2,279 $\mathrm{m}$ a.s.I.) Mountains, which means by some $20 \mathrm{~km}$ east was reported (Kucsicsa, 2013). In addition, the presence of marmots was also indicated in the surrounding areas, in the north-bordering Maramureş Mountains, more precisely just below the Toroioaga Peak (1,930 m a.s.l) situated towards the southern end (Nădișan, 2000).

The life of these animals (very fond of quiet) was disturbed by grazing and tourism, some of them being occasionally killed, e.g. one in 1977 by shepherd dogs close to Buhăescu Lake, and another in 1978 near the Gărgălău Peak (both in the Rodna Mountains).

Although proposals for the introduction of this species in Romania's fauna had been made as early as 1949, it was only in 1965 that the Făgăraş and the Retezat mountains were chosen as population sites. In the early 1970 s some would suggest the Rodna Mountains, as well.

Despite the fact that galleries to shelter them had been built in all the three massifs, the alpine marmots quickly deserted them, digging themselves new ones, closer to, or remoter from those made by man, the new environment was seemingly better and more propitious.

The alpine marmot sites are shared also with the chamois (Rupicapra rupicapra) and although both species are herbivorous, yet the wealth of food makes them live in ecological "harmony ", as it were. Thereby, in case of danger, alpine marmots would worn the chamois of an enemy approach by emitting more sonorous and powerful signals than the latter do.

The three populations introduced in 1973 increased fifteen times over the last four decades, from 50 to 747 individuals, namely $50 \%$ in Rodna, $30 \%$ in Retezat and $20 \%$ in Făgăraş mountains (Fig. 8).

A typical alpine rodent, the alpine marmot got perfectly integrated into the new habitats of alpine landforms and alpine meadows of the three mountain zones, each mountain range hosting several alpine marmot colonies. They would extend their areas (up to $20 \mathrm{~km}$ ) in other favourable zones, most often being seen in the screes adjoining the alpine meadows where they found shelter and food.
Newly reintroduced in the Carpathian Mountains, and in Romania for that matter, alpine marmots have been protected all along in the Retezat Mountains National Park, the Pietrosul Rodnei Nature Reserve and Arpăşelului Valley Nature Reserve, the firs sites of their release. Under Law No. 13, 1993 on Romania's adherence to the Convention for the Conservation of Wildlife and Natural Habitats, adopted in Bern in 1979, the alpine marmot becomes a protected animal. Thus, alpine marmot areas in the Retezat and the Rodna Mountains are nowadays part of the homonymous National Parks established in 1935 and 1990, respectively (Buza et al., 2005). Protection of the alpine marmot species is stipulated also by Law No. 462, 2001, on the regime of protected areas and conservation of natural habitats, of wild flora and fauna.

\section{Acknowledgments}

The researches were undertaken in the framework of the project entitled Studies on the national parks in Romania supported by the Romanian Academy (2011-2012). Thanks are due also to Eng. P. Gărgărea from the National ForestAdministration.

\section{References}

Allainé, D., I. Rodrigue, M. Le Berre and R. Ramousse : Habitat preferences of Alpine marmots, Marmota marmota. Canadian J. of Zoo., 72, 2193-2198 (1994).

Almăşan, H.: Dispariția, reaclimatizarea şi aclimatizarea unor specii de animale sălbatice în România [Disappearance, reacclimatization and acclimatization of wild animal species in Romania]. Vânătorul şi Pescarul Sportiv, 4, 12-14 (1965) (in Romanian).

Almăşan, H.: Situaţia actuală a răspândirii marmotei în România [The present situation of alpine marmots distribution in Romania]. Vânătorul şi Pescarul Sportiv, 6, 8-9 (1981) (in Romanian).

Almăşan, H., V. Soran, M. Borcea, D. Munteanu and G. Coldea : Consideraţii privind structura trofică a biomurilor din Munţii Retezat [Considerations regarding the trophic structure of biomes in the Retezat Mountains]. Ocrotirea Naturii şi a Mediului Înconjurător, Bucureşti, XXX, 13-24 (1986).

Bačkor, P.: Current distribution of the Alpine marmot (Marmota marmota) in the Nizke Tatry Mts., Slovakia (Rodentia: Sciuridae). Lynx, 40, 513 (2009).

Bălteanu, D., M. Dumitraşcu, D. Ciupitu and S. Geacu : Natural protected areas. In Romania. Space-Society-Environment. Edit. Academiei Române, Bucureşti, pp. 328-340 (2006).

Benedek, A. M.: Dynamics of small mammals' communities (Insectivora and Rodentia) from Retezat Mountains National Park (Romania). Trav. Mus. Nat. Hist. Natl. "Gr. Antipa, 49, 401-409 (2006).

Benedek, A. M.: Comunităţi de mamifere mici (ordinele Soricomorpha şi Rodentia) din Transilvania [Communities of small mammals (Soricomorpha and Rodentia Orders) in Transylvania]. Editura Universităţii "Lucian Blaga" Sibiu (2014).

Bielz, E. A.: Die Fauna der Wierbeltiere Siebenbürgens nach ihrem gegenwartigen Stande. Verhandlungen und Mittheilungen des Siebenbürgischen Vereins für Naturwissenschaften zu Hermanstadt, 38, 15-36 (1888).

Borgo, A.: Habitat requirements of the Alpine marmot Marmota mannota in reintroduction areas of the Eastern Italian Alps. Formulation and validation of habitat suitability models. Acta Theriologica, 48, 557-569 (2003). 
Buza, M., S. Geacu and M. Dumitrașcu : Die Nationalparks in Rumänien im Kontext der EU-Erweiterung. Ein Überblick [The National Parks in Romania in the context of European Union Enlargement. A cultural cross-section]. Europa Regional, Leipzig, 13,115-122 (2005), (in German).

Călinescu, R. : Mamiferele României. Repartiţia şi problemele lor biogeografice - economice [The mammals of Romania : The spread and their biogeographicnand economic concerns]. Buletinul Ministerului Agriculturii şi Domeniilor, 251, 1-103. (1931) (in Romanian).

Chiş, V.T.: Geographical introductory characterization of the Rodna mountains - Rodna Mountains National Park (Eastern Carpathians, Romania), Transylv. Rev. Syst. Ecol. Res., 9,1-14 (2010).

Csató, von: A Retyezát helyviszoni és természetrajzi tekintetben [The local conditions and natural history context of Retezat]. Erd. Muz. Egyl. Evk., 4, 75-76 (1866-1867) (in Hungarian).

Dolenec, Z. and P. Dolente : Influence of the local spring warming on the breeding phenology in blackcap (Sylvia atricapilla) in Croatia. J. Environ Biol., 32, 625-627 (2011).

Dragne, D., S. Cheval and M. Micu : The snow cover in the Romanian Carpathians and the influencing factors. Analale Universităţii de Vest din Timişoara, XIV, 145-159 (2004).

Dragotă, C.S. and G. Kucsicsa : Global climate change-related particularities in the Rodnei Mountains National Park. Carpathian J. Earth Enviro. Sci., 6, 43-50 (2011).

Filipaşcu, Al.: Marmota în sălbăticiuni din vremea strămoşilor noştri [The alpine marmot in the wilderness if our ancestors]. Edit. Ştiinţifică, Bucureşti, (1969) (in Romanian).

Gâştescu, P.: Lacurile din România, Limnologie regională [The Lakes of Romania. Regional Limnology]. Edit. Academiei Române, Bucureşti, (1971) (in Romanian).

Geacu, S.: Caracteristicile faunei terestre a Românie [Characteristics of the terrestrial fauna of Romania]. Terra, XXXV, 17-23 (2006) (in Romanian).

Herrero, J., R. García-González and A. García-Serrano : Altitudinal distribution of Alpine marmot (Marmota mannota) in the Pyrenees, Spain/France. Arctic Alpine Res., 26, 328-331, (1994).

Inouye, D.W., B. Barr, K.B. Armitage and B.D. Inouye : Climate change is affecting altitudinal migrants and hibernating species. Proc. Nat. Acad. Sci. USA, 97, 1630-1633 (2000).

Kucsicsa, G. : Parcul Naţional Munţii Rodnei. Relații om-mediu [The Rodna Mountains National Park. Human-environment interactions], Edit. Universitară, Bucureşti (2013) (in Romanian with English summary).

Law no. 13 on the adhesion of Romania to the Convention regarding European wild life and natural habitats conservation adopted in 1979 in Bern, Romanian Government, Monitorul Oficial al României, 62,25 martie 1993, Bucureşti (in Romanian).

Law no. 462 on the regime of natural protected areas and the conservation of natural habitats, wild flora and fauna, Romanian Government, Monitorul Oficial al României, 433, 2 august 2001, Bucureşti (in Romanian).
Nădişan, I.: Pietrosul Rodnei - Rezervație a Biosferei [Pietrosul RodneiBiosphere Reserve]. Edit. Muzeul Județean Maramureş, Baia Mare (2000) (in Romanian).

Niculescu, G.: Procese de modelare actuală, relieful glaciar şi crionival, [Present-day processes, glacial and periglacial relief], Plate III-2 in Atlas R. S. România Inst. Geogr., Edit. Academiei Române, Bucureşti (1973) (in Romanian).

Niculescu, Gh, and L. Badea : The Romanian Carpathian Mountains and the Transylvanian Tableland. In Romania. Space-SocietyEnvironment. Edit. Academiei Române, București, pp. 60-69 (2006).

Pânzariu, G.: Marmota (Marmota marmota L.) în Munţii Rodnei, după 20 de ani de la colonizare [The Marmot (Marmota marmota L.) in the Rodna Mountains, 20 years after the settlement], Ocrotirea Naturii şi a Mediului Înconjurător, Bucureşti, 37, 11-18 (1993).

Pişotă, I.: Lacurile glaciare din Carpaţii Meridionali [The glacial lakes in the Southern Carpathians]. Edit. Academiei Române, Bucureşti, (1971) (in Romanian).

Popovici, I.: Parcul Naţional Retezat. Studii ecologice [Retezat National Park. Ecological studies]. Edit. West Side, Braşov (1993) (in Romanian).

Rosetti-Bălănescu, C.: Despre neprezenţa marmotei în Carpaţi româneşti. [About the nonexistence of alpine marmot in the Romanian Carpathians]. Ocrot. Nat, 17., 211-215. (1973) (in Romanian).

Sandu I., V. Pescaru, I. Poiană, A. Geicu, I. Cândea and D. Ţâştea : Clima României [The Climate of Romania]. Edit. Academiei Române, Bucureşti (2008) (in Romanian).

Szabo, B.M.: Data on the distribution of Marmota marmota (Rodentia, Sciuridae) from the Rodna Mountains National Park (Eastern Carpathians, Romania). Transylv. Rev. Syst. Ecol. Res., 9, 205$210(2010)$

Urdea, P.: Munţii Retezat. Studiu geomorfologic [The Retezat Mountains. Geomorphological study], Edit. Academiei Române, Bucureşti (2000) (in Romanian with English summary)

Urdea, P.: Glacial relief and pleistocene glaciation in Retezat Mountains (Transylvanian Alps, Romania). Geographica Pannonica, 5, 4-7 (2001).

Velcea, V. and A. Popova-Cucu : Munţii Făgăraş-lezer [The Făgăraşlezer Mountains]. In : Geografia României. Vol. 3, Edit. Academiei Române, Bucureşti (1987) (in Romanian).

Voiculescu, M. and F. Ardelean : Snow avalanche - disturbance of high mountain environment. Case study - the Doamnei glacial valley the Făgăraş Massif-Southern Carpathians, Romanian Carpathians, Carpathian J. of Earth Environ. Sci., 7, 95-108 (2012).

Voiculescu, M. : Studiul potenţialului geoecologic al Masivului Făgăraş şi protecţia mediului înconjurător [The study of the geoecologic potential of the Făgăraş Massif and environmental protection]. Edit. Mirton, Timişoara (2002) (in Romanian).

Wilson, D. E. and D. M. Reeder : Mammals species of the World. A taxonomic and geographic reference. Smithsonian Institution Press. Washington and London (1993). 